\title{
SITE INDEX PREDICTION OF SMALLHOLDER PLANTATIONS OF KAYU BAWANG (Disoxylum mollissimum Blume) IN BENGKULU PROVINCE
}

\author{
Hengki Siahaan* and Agus Sumadi \\ Palembang Forestry Research Institute \\ Jl. Kol H. Burlian Km 6,5 Puntikayu Palembang, Indonesia
}

Received: 13 November 2013, Revised: 10 September 2015, Accepted: 12 September 2015

\begin{abstract}
SITE INDEX PREDICTION OF SMALLHOLDER PLANTATIONS OF KAYU BAWANG (Disoxylum mollissimum Blume) IN BENGKULU PROVINCE. Kayu bawang (Dysoxylum mollissimum Blume) has been planted almost in all districts of Bengkulu Province, Indonesia, but yet no study has been conducted to analyze the site quality of this species. This paper studies the site quality of Dysoxylum mollissimum Blume of smallholder plantations by establishing 32 permanent sample plots (PSPs) distributed in six districts of Bengkulu Province and measured periodically from 2006 to 2012. Site quality was determined by phytocentric method which used stand dominant height as a indicator. The result shows that the best model for dominant height growth of Dysoxylum mollissimum Blume in Bengkulu Province was the Schumacher model expressed by the equation: $\mathrm{Ln} H \mathrm{Ho}=(3.06+\mathrm{ai})-2.05 / \mathrm{A}(\mathrm{R} 2=96.5 \%$, Absolute Mean Residual (AMRES) $=0.82$ and Average Percentage Difference $(A P D)=5.03 \%$ ). The relevant site equation for this species derived from the dominant height growth model was: $\mathrm{Ln} \mathrm{Si}=\mathrm{Ln} \mathrm{H0}-2.05$ (1/12-1/A) for an index age of 12 years. Based on this equation, the sites were classified into 5 classes having an equal range of $3 \mathrm{~m}$ i.e. SI $<16 \mathrm{~m}$; $16 \mathrm{~m} \leq \mathrm{SI}<19 \mathrm{~m} ; 19 \mathrm{~m} \leq \mathrm{SI}<22 \mathrm{~m} ; 22 \mathrm{~m} \leq \mathrm{SI}<25 \mathrm{~m}$; and SI $\geq 25 \mathrm{~m}$ : for site classes I, II, III, IV, and V representing from the lowest to the highest productivity respectively. Site class I, the poorest site, was found on the upland areas with an altitude of $>850 \mathrm{~m}$ above sea level on andosol soil type. Adversely, the best site (site class V) was found at lowland areas with an altitude of $<300 \mathrm{~m}$ above sea level and on ultisol soil type.
\end{abstract}

Keywords: Dysoxylum mollissimum, smallholder plantation, growth, and site index

PENDUGAAN KUALITAS TEMPAT TUMBUH PADA HUTAN RAKYAT KAYU BAWAN (Disoxylum mollissimum Blume) SKALA KECIL DI PROVINSI BENGKULU. Kayu bawang (Dysoxylum mollissimum Blume) telah ditanam pada hampir semua kabupaten di Provinsi Bengkulu, Indonesia, tetapi belum ada penelitian yang dilakukan untuk pendugaan kualitas tempat tumbuh jenis ini. Tulisan ini mempelajari kualitas tempat tumbuh penanaman kayu bawang skala kecil dengan membangun 32 petak ukur permanen yang terdistribusi pada 6 kabupaten di Provinsi Bengkulu dan diukur secara periodik dari tabun 2006 - 2012. Kualitas tempat tumbuh ditentukan dengan metode phytocentric menggunakan peninggi tegakan sebagai indikator. Hasil penelitian menunjuk.kan bahwa model yang akurat untuk menduga pertumbuhan peninggi kayu bawang adalab model Schumacer dengan persamaan $\mathrm{Ln} H o=(3,06+$ ai) $-2,05 / \mathrm{A}$ (R2 $=96,5 \%, A M R E S=0,82$ dan $A P D=5,03 \%)$. Persamaan kualitas tempat tumbuh, yang diformulasikan dari model pertumbuhan peninggi adalab Ln Si $=\mathrm{Ln}$ HO - 2,05 (1/12-1/A) dengan umur indeks 12 tabun. Berdasarkan persamaan ini, tempat tumbub kayu bawang diklasifikasikan ke dalam 5 kelas dengan interval kelas $3 \mathrm{~m}$, yaitu $S I<16 \mathrm{~m} ; 16 \mathrm{~m}$ $\leq S I<19 m ; 19 m \leq S I<22 m ; 22 m \leq S I<25 m$; and SI $\geq 25$ untuk kelas tapak. I, II, III, IV, dan V yang secara berturut-turut merepresentasikan produktifitas paling rendab bingga yang tertinggi. Kualitas tempat tumbub I yang mempunyai kualitas terendah umumnya ditemukan pada dataran tinggi dengan ketinggian $>850 \mathrm{~m}$ dpl dengan jenis tanah andosol, sebaliknya kualitas tanah $V$ (kualitas terbaik) dijumpai pada dataran rendah dengan ketinggian tempat $<300 \mathrm{~m}$ dpl yang berasal dari jenis tanah ultisol.

Kata kunci: Dysoxylum mollissimum, penanaman skala kecil, pertumbuban, dan indeks tapak

*Corresponding author: hengki_siahaan@yahoo.co.id 


\section{INTRODUCTION}

Kayu bawang (Disoxylum mollissimum Blume) is a local tree species of Meliaceae family and grow naturally in Bengkulu Province especially in North Bengkulu District. Since 1990, it has been planted by smallholder farmers in Bengkulu Province as a timber tree. This tree species can grow well in various sites and climatic conditions. It is well adapted to a wide range of rainfall, from 500 to $3500 \mathrm{~mm}$ year ${ }^{-1}$ and altitude from 0 to $1000 \mathrm{~m}$ above sea level (Forest District of Bengkulu, 2003). Farmers use kayu bawang as a timber source for construction material and furniture.

Smallholder plantations have specific characteristics reflecting various site management practices. The tree is grown usually in a small scale plantation comprising of a few hundred trees per household (Vanclay, Baynes, \& Cedarnon, 2008). Despite grown in small scale plantations, kayu bawang has grown almost in all districts of Bengkulu Province. The farmers usually grow kayu bawang in agroforestry system with coffee and/or cacao (Siahaan, Suhendang, Rusolono, \& Sumadi, 2011) as shown in Figure 1. Silvicultural practices applied for kayu bawang plantations vary considerably among the farmers, such as stand density (spacing), tending, and thinning regimes. Stand density varied from 150 to 1250 stems ha $a^{-1}$ (Siahaan et al., 2011).

Although kayu bawang has been planted

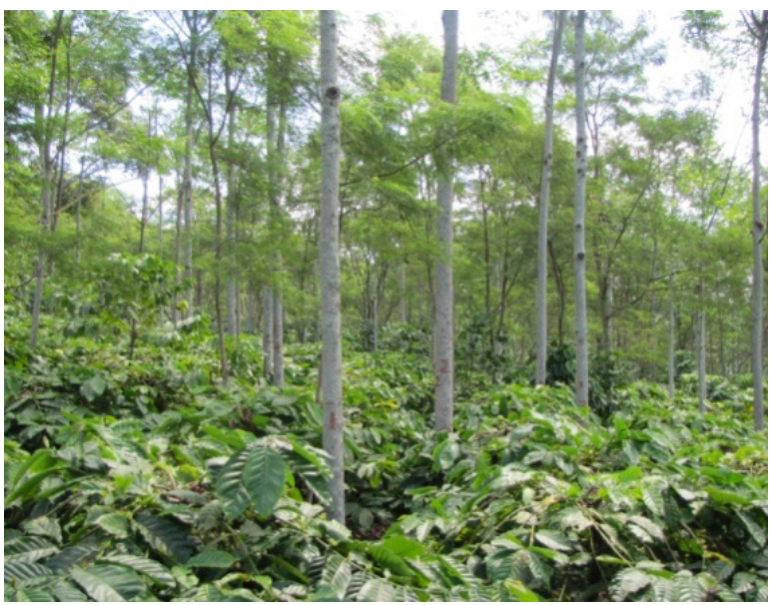

almost in all districts of Bengkulu Province, research regarding site quality and its distribution is very limited. The effective management of forest plantations can be hindered if information on growth and yield of the tree plantations is limited (Krisnawati, 2007). Research on growth and yield of kayu bawang has been conducted by establishing permanent sample plots (PSPs) in Bengkulu Province, starting in 2006. Several publications on growth and yield of kayu bawang are available, including growth of monoculture plantations in North Bengkulu (Apriyanto, 2003), growth models for various planting patterns in Bengkulu Province (Siahaan et al, 2011) and tree volume estimation model (Sumadi \& Siahaan, 2010); however up to present there is no quantitative information about its site quality.

Site quality can be defined as the potential of a site to produce timber or forest biomass for a particular tree species and forest type (Clutter, Pienar, Brister, \& Bailey, 1983; Skovsgaard \& Vanclay, 2008). Conceptually, site quality is considered as an inherent property of plots of land, whether or not trees are being grown at the time of interest (Beaulieu, Raulier, Pregent, \& Bousquet, 2011). Site quality is commonly expressed by the site index, defined as the dominant height of a stand at a reference age (Avery \& Burkhart, 2002). Dominant height is a good indicator of site quality of a particular site because it almost entirely insensitive to stand

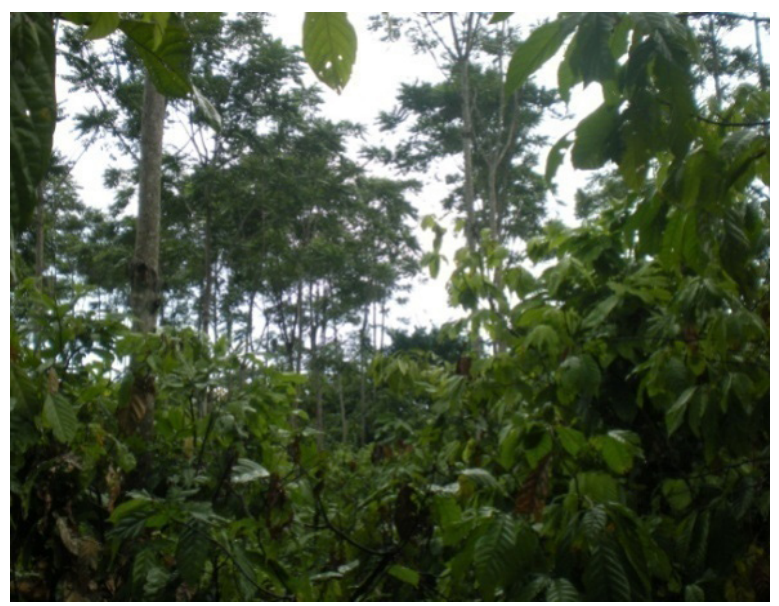

Figure 1. Agroforestry kayu bawang + coffee (left) and kayu bawang + cacao (right) smallholder plantations of kayu bawang in Bengkulu Province 
density and thinning regimes (Alder, 1980). In order to facilitate the application of site index model to a broader range of situation, some researcher incorporated climatic, edaphic, and physiographical aspects in the model development (Ovideo, Tome, Bravo, Montero, \& del Rio, 2008; Beulieu et al., 2011; Khouri, Alvarez, Lopez, Prendes, \& Obregon, 2011; Sharma, Brunner, \& Eid, 2012; and Scolforo, Maesti, Filho, de Mello, de Oliveira, \& de Assis, 2013).

Information on site quality is an important prerequisite for forest management planning (Sharma et al., 2012). For kayu bawang tree species, this information is required by the government (District Forestry Agency), the farmers and the other relevant forestry stakeholders. The government use the information of site quality to select the site where plantations will be established, while the farmer or landowner use it to implement the optimum management planning under certain conditions of demand, productivity, cost of silviculture and harvesting (Scolforo et al., 2013). This paper describes quantification of site quality of smallholder plantations of kayu bawang in Bengkulu Province to fill the information gap concerning growth of this species. Climatic and edaphic conditions are described for each site class in order to increase its application for management planning of this tree species.

\section{MATERIAL AND METHOD}

\section{A. Data Description}

Research was conducted from 2006 to 2012 on smallholder plantations of kayu bawang by establishing 32 permanent sample plots (PSPs) in a square shape of $30 \mathrm{~m} \times 30 \mathrm{~m}$, distributed over six districts of Bengkulu Province. The PSPs were located in North Bengkulu (11 PSPs), Central Bengkulu (7 PSPs), Rejang Lebong (6 PSPs), Kepahiang (1 PSP), Seluma (3 PSPs), and South Bengkulu (4 PSPs) Districts (Table 1, Figure 2). Almost all plots were initially planted in agroforestry system with coffee. Only 2 plots in Talang IV, Central Bengkulu and 1 plot in Kampung Delima, Rejang Lebong were in an agroforestry system with cacao.

Permanent sample plots were established by selecting smallholder plantations with relative equal frequency of various site quality, stand density and age class. Based on these criteria, PSPs were established on sites with altitude

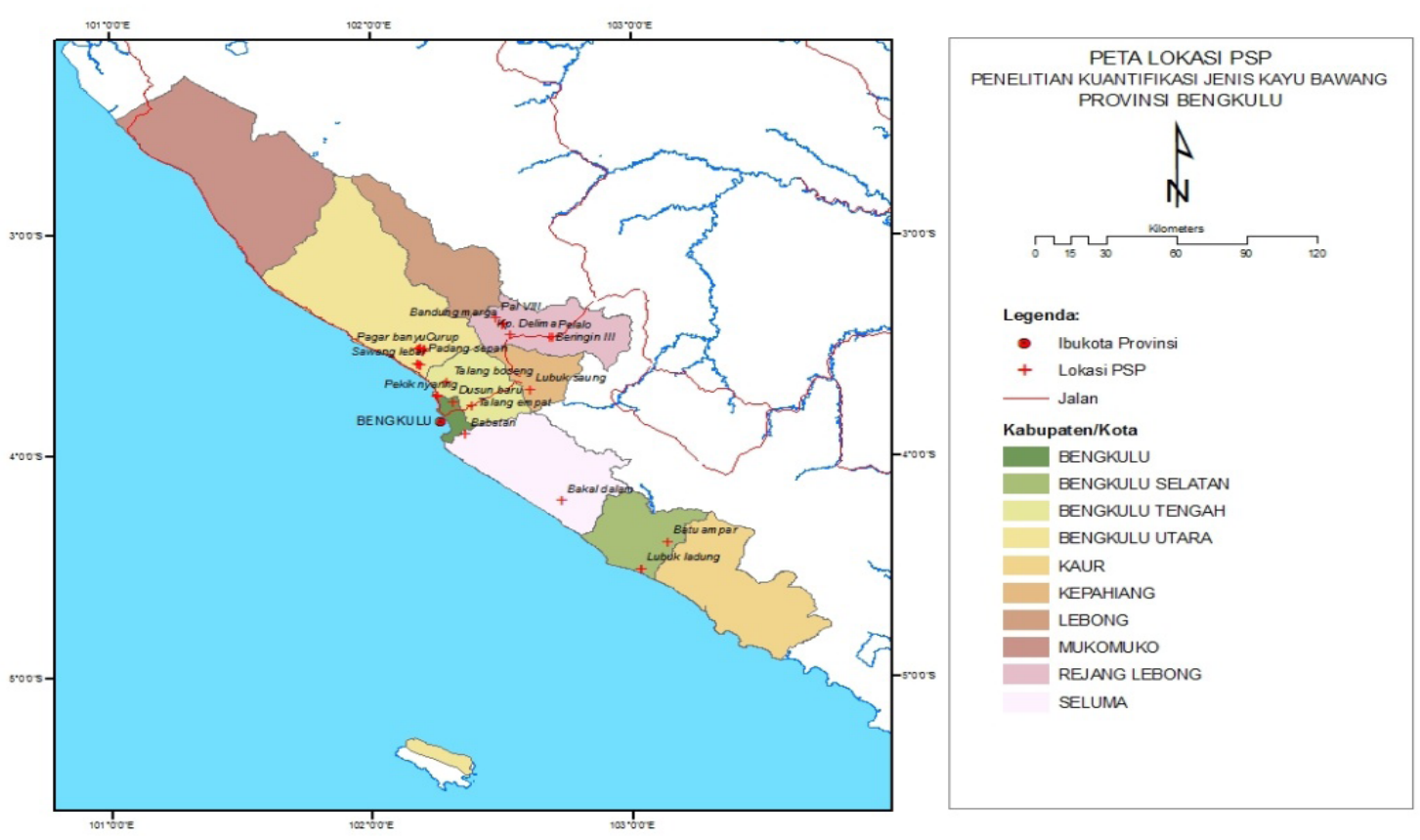

Figure 2. Map of permanent sample plots (PSPs) for site quantification of kayu bawang in Bengkulu Province 
Table 1. List of PSPs locations for Kayu bawang Site Quantification in Bengkulu Province

\begin{tabular}{|c|c|c|c|c|}
\hline No. & District & Village (number of plot) & Geographycal coordinate & Altitude(m) \\
\hline \multirow[t]{5}{*}{1.} & \multirow{5}{*}{$\begin{array}{l}\text { North } \\
\text { Bengkulu }\end{array}$} & Sawang Lebar (4) & $102^{\circ} 10^{\prime} 49^{\prime \prime} \mathrm{E} ; 03^{\circ} 35^{\prime} 07^{\prime \prime} \mathrm{S}$ & $46-56$ \\
\hline & & Dusun Curup (2) & $102^{\circ} 11^{\prime} 20^{\prime \prime} \mathrm{E} ; 03^{\circ} 30^{\prime} 54^{\prime \prime} \mathrm{S}$ & $86-88$ \\
\hline & & Genting Perangkap (2) & $102^{\circ} 10^{\prime} 50^{\prime \prime} \mathrm{E} ; 03^{\circ} 31^{\prime} 16^{\prime \prime} \mathrm{S}$ & $91-95$ \\
\hline & & Padang Sepan (1) & $102^{\circ} 11^{\prime} 53^{\prime \prime} \mathrm{E} ; 03^{\circ} 31^{\prime} 50^{\prime \prime} \mathrm{S}$ & 86 \\
\hline & & Pagar Banyu (2) & $102^{\circ} 12^{\prime} 07^{\prime \prime} \mathrm{E} ; 03^{\circ} 31^{\prime} 08^{\prime \prime} \mathrm{S}$ & 106 \\
\hline \multirow[t]{5}{*}{2.} & \multirow{5}{*}{$\begin{array}{l}\text { Central } \\
\text { Bengkulu }\end{array}$} & Pasar Pedati (2) & 102'14’35”E; 0343’11” S & 24 \\
\hline & & Pekik Nyaring (2) & $102^{\circ} 15^{\prime} 10^{\prime \prime} \mathrm{E} ; 03^{\circ} 43^{\prime} 59^{\prime \prime} \mathrm{S}$ & 8 \\
\hline & & Talang Boseng (1) & $102.29185^{\circ} \mathrm{E} ; 03.66858^{\circ} \mathrm{S}$ & 52 \\
\hline & & Dusun Baru (1) & $102.31565^{\circ} \mathrm{E} ; 03.76000^{\circ} \mathrm{S}$ & 80 \\
\hline & & Talang Empat (1) & $102.38407^{\circ} \mathrm{E} ; 03.77526^{\circ} \mathrm{S}$ & 59 \\
\hline \multirow[t]{3}{*}{3.} & \multirow{3}{*}{$\begin{array}{l}\text { South } \\
\text { Bengkulu }\end{array}$} & Batu Ampar (1) & $103.13814^{\circ} \mathrm{E} ; 04.39450^{\circ} \mathrm{S}$ & 277 \\
\hline & & Lubuk Ladung (2) & $103.03434^{\circ} \mathrm{E} ; 04.51560^{\circ} \mathrm{S}$ & 96 \\
\hline & & Pagar Dewa (1) & 102.53’52” E; 4'26’11” S & 25 \\
\hline \multirow[t]{3}{*}{4.} & \multirow[t]{3}{*}{ Seluma } & Bakal Dalam (1) & $102.73258^{\circ} \mathrm{E} ; 04.20771^{\circ} \mathrm{S}$ & 43 \\
\hline & & Taba (1) & $102.73261^{\circ} \mathrm{E} ; 04.20766^{\circ} \mathrm{S}$ & 33 \\
\hline & & Babatan (1) & $102.35807^{\circ} \mathrm{E} ; 03.90380^{\circ} \mathrm{S}$ & 8 \\
\hline 5. & Kepahiang & Lubuk Saung (1) & $102.60946^{\circ} \mathrm{E} ; 03.70277^{\circ} \mathrm{S}$ & 529 \\
\hline \multirow[t]{5}{*}{6.} & \multirow{5}{*}{$\begin{array}{l}\text { Rejang } \\
\text { Lebong }\end{array}$} & Bandung Marga (2) & $102.50582^{\circ} \mathrm{E} ; 03.40670^{\circ} \mathrm{S}$ & $885-891$ \\
\hline & & Pal VIII (1) & $102.47994^{\circ} \mathrm{E} ; 03.37851^{\circ} \mathrm{S}$ & 923 \\
\hline & & Kp. Delima (1) & $102.53171^{\circ} \mathrm{E} ; 03.45536^{\circ} \mathrm{S}$ & 694 \\
\hline & & Pelalo (1) & $102.69809^{\circ} \mathrm{E} ; 03.46332^{\circ} \mathrm{S}$ & 873 \\
\hline & & Beringin III (1) & $102.68678^{\circ} \mathrm{E} ; 03.46524^{\circ} \mathrm{S}$ & 974 \\
\hline
\end{tabular}

Remark: Map of these geographical coordinates is presented in Figure 2

ranging from 8 to $974 \mathrm{~m}$ above sea level, rainfall from 2002 to $3956 \mathrm{~mm} /$ year, stand density from 150 to 1389 trees/ha, and stand age ranged from 2 to 13 years. Data from 32 PSPs consisted of 184 measurements which were divided into two parts for fitting and validation models. Fitting model used data from 20 PSPs consisting of 121 measurements and the remaining 12 PSPs (63 measurements) were used for validation. Statistical description of fitting and validation data regarding dominant height is shown in Table 2. Each PSP was generally measured periodically once a year from 2006 to 2012 so each plot was measured seven times but several PSPs were cut during the measurement period.

\section{B. Soil Sampling and Climatic Data Collection}

Soil samples were collected from each plot using two methods. The first method was collecting soil samples from four sides of the soil profiles at a depth of $0-30 \mathrm{~cm}$ and $30-60$ $\mathrm{cm}$. The samples from the same depth were pooled as a composite sample from each plot. The second method was collecting soil samples by using a ring sample at the same depth as the first method. The properties of the soil samples were analyzed in the soil laboratory. The samples collected by the first method were analyzed to get information on texture, $\mathrm{pH}$, organic matter, nutrient content $(\mathrm{N}, \mathrm{P}, \mathrm{K}, \mathrm{Ca}$, 
Table 2. Statistic description of fitting and validation data models for dominant height growth of kayu bawang in Bengkulu Province

\begin{tabular}{ccccccccccc}
\hline & \multicolumn{9}{c}{ Fitting data } \\
\cline { 2 - 11 }$($ year $)$ & $\mathbf{n}$ & $\begin{array}{c}\text { Mean } \\
(\mathbf{m})\end{array}$ & $\begin{array}{c}\text { SD } \\
(\mathbf{m})\end{array}$ & $\begin{array}{c}\text { Min } \\
(\mathrm{m})\end{array}$ & $\begin{array}{c}\text { Max } \\
(\mathrm{m})\end{array}$ & $\mathbf{n}$ & $\begin{array}{c}\text { Mean } \\
(\mathrm{m})\end{array}$ & $\begin{array}{c}\text { SD } \\
(\mathrm{m})\end{array}$ & $\begin{array}{c}\text { Min } \\
(\mathrm{m})\end{array}$ & $\begin{array}{c}\text { Max } \\
(\mathrm{m})\end{array}$ \\
\hline 2 & 12 & 8.15 & 1.82 & 4.3 & 11.1 & 6 & 10.32 & 1.37 & 8.7 & 11.9 \\
3 & 4 & 10.38 & 2.37 & 7.1 & 12.4 & 4 & 11.38 & 2.43 & 8.0 & 13.5 \\
4 & 8 & 12.75 & 2.40 & 8.7 & 15.5 & 4 & 14.68 & 2.67 & 11.7 & 18.2 \\
5 & 8 & 13.82 & 3.12 & 6.9 & 16.6 & 4 & 14.22 & 1.81 & 11.9 & 15.9 \\
6 & 9 & 16.28 & 3.62 & 8.3 & 20.4 & 5 & 18.52 & 2.32 & 14.5 & 20.5 \\
7 & 5 & 16.82 & 4.22 & 10.5 & 22.2 & 4 & 20.13 & 3.59 & 16.5 & 23.6 \\
8 & 13 & 16.65 & 2.86 & 11.4 & 23.4 & 8 & 18.65 & 3.19 & 11.2 & 21.4 \\
9 & 14 & 17.62 & 3.08 & 11.9 & 23.6 & 8 & 20.59 & 3.54 & 14.0 & 25.8 \\
10 & 18 & 19.27 & 2.45 & 14.1 & 23.9 & 8 & 23.20 & 4.10 & 14.5 & 26.9 \\
11 & 14 & 20.31 & 2.92 & 14.2 & 25.2 & 6 & 23.10 & 4.59 & 14.9 & 28.3 \\
12 & 9 & 21.01 & 3.82 & 14.6 & 26.2 & 6 & 22.40 & 5.77 & 15.3 & 28.5 \\
13 & 7 & 21.29 & 3.81 & 14.6 & 27.9 & & & & & \\
\hline Total & 121 & & & & & 63 & & & & \\
\hline
\end{tabular}

Table 3. Statistic description of fitting and validation data models for dominant height growth of kayu bawang in Bengkulu Province

\begin{tabular}{cccccc}
\hline Equation & $\mathbf{a}_{\mathbf{0}}$ & $\mathbf{b}$ & $\mathbf{R}^{\mathbf{2}} \mathbf{( \% )}$ & AMRES & APD (\%) \\
\hline $\mathrm{Ln} \mathrm{H}_{0}=\left(3.06+\mathrm{a}_{\mathrm{i}}\right)-2.05 / \mathrm{A}$ & 3.06 & -2.05 & 96.5 & 0.82 & 5.03 \\
\hline $\mathrm{H}_{0}=\left(1.92+\mathrm{a}_{\mathrm{i}}\right)+7.18 \ln \mathrm{A}$ & 1.92 & 7.18 & 96.0 & 0.95 & 32.48 \\
\hline
\end{tabular}

$\mathrm{Mg}$ ), and cation exchange capacity. The samples collected by the second method were analyzed to get information on bulk density. Rainfall data were collected from the Indonesian Agency for Meteorology, Climatology and Geophysics.

\section{Procedure for Developing Site Index Model}

Site index model was developed by establishing a $100 \mathrm{~m} \times 100 \mathrm{~m}$ PSP. Dominant height is defined as the average of the 100 highest trees or the average height of the 100 largest DBH trees per hectare. The latter definition has been used by Krisnawati, Wang, Ades, and Wild (2009) to model site index of
Acacia mangium plantations in South Sumatra. Due to the small area of smallholder plantations of kayu bawang in the study sites, quantification of site quality of kayu bawang was conducted through establishing square PSPs of $30 \mathrm{~m} \times 30$ $\mathrm{m}$. For each PSP, heights of the 10 dominant trees were measured with a laser dendrometer. The average heght of the 10 dominant trees was used as dominant height (Ho) and as an indicator of the site quality.

Site quality is expressed in an equation as a relationship of dominant height over stand age. The site index equation was developed by the guide curve method. The guide curve method is used to generate a set of anamorphic site 
index curves. Two non linear models were selected as candidates for the base equation. These were the Schumacher model (used by Alder, 1980) and the model used by Avery and Burkhart (1994). These two models and its derivative models were commonly used to model site index for some forest plantations in Indonesia (e.g. Harbagung (1991); Puspasari \& Achmad (2000) for Acacia mangium and Darwo, Suhendang, Jaya, and Purnomo (2012) for Eucalyptus. The two models are:

Ln $\mathrm{Ho}=\mathrm{a}+\mathrm{b} / \mathrm{A} \quad$ (Schumacer, 1937)

Ho $=\mathrm{a}+\mathrm{b}(\mathrm{Ln}$ A) (Avery and Burkhart, 1994)...(2)

Where:

Ho $=$ dominant height $(\mathrm{m}), \mathrm{A}=$ stand age (year), $a$, and $b=$ coefficients

Data from each PSP were analyzed by applying a nested regression to differentiate the site quality difference of each plot. The difference of site quality between plots is expressed by different intercept as shown in equation 3 and 4 as:

$\mathrm{Ln} \mathrm{Ho}=(\mathrm{a} 0+\mathrm{ai})+\mathrm{b} / \mathrm{A}$

$\mathrm{Ho}=(\mathrm{a} 0+\mathrm{ai})+\mathrm{b}(\operatorname{Ln} \mathrm{A})$

Where:

$\mathrm{A}=$ stand age (year), $\mathrm{a} 0=$ intercept for plot 1 , $a i=$ differential intercept for the-i plot; $(i=2$, $3, \ldots 32)$

Site quality index is the dominant height at a reference age called the index age. For kayu bawang, an index age of 12 year was selected, which is approximately its rotation age. If the age of a stand is below the reference age, site index is estimated by the following equation:

$\mathrm{Ln} \mathrm{Si}=\mathrm{Ln} \mathrm{H} 0+\mathrm{b}(1 / \mathrm{Ai}-1 / \mathrm{A})$.

$\mathrm{SI}=\mathrm{H} 0+\mathrm{b}(\ln \mathrm{Ai}-\ln \mathrm{A})$

Where:

$\mathrm{SI}=$ site index, $\mathrm{Ho}=$ dominant height $(\mathrm{m}), \mathrm{A}=$ stand age (year), and $\mathrm{Ai}=$ index age

\section{Model Evaluation}

Besides biological or logical consideration of kayu bawang's height growth, model evaluation was conducted based on both model's fitting and validation statistics. There are several statistical fitting models which are usually used for model evaluation such as asymptotic t-statistic, adjusted coefficient of determination $\left(\mathrm{R}_{\text {adj }}^{2}\right)$, root mean square error, and residual analysis (Krisnawati et al., 2009). Darwo et al. (2012) used a coefficient of determination $\left(\mathrm{R}^{2}\right)$ and variance analysis (F-test). For this evaluation purpose, the fit statistic used was the coefficient of determination $\left(\mathrm{R}^{2}\right)$, because evaluation of regression analysis based on $\mathrm{R}^{2}$ as a single criteria has the same result as the evaluation that included other statistical criteria simultaneously. It can be proven that other statistical tests like mean square error (MSE) and F-value can be derived from the value of $\mathrm{R}^{2}$.

Model validation is aimed to see if the quality of the fit reflects the quality of the predictions. Several validation statistics recommended by Huang, Yang, and Wang (2003) and used by Krisnawati et al. (2009) for Acacia mangium plantations in South Sumatra are: mean residual (MRES), absolute mean residual (AMRES), root mean square error (RMSE), and the adjusted model efficiency (MEF adj). Husch et al. (1963) recommended aggregate difference (AD) and average percentage deviation (APD) as used by Harbagung (1991). For this evaluation, two validation statistics, the mean residual (MRES) and the average percentage deviation (APD) were used and calculated by the following formula:

\section{RESULT AND DISCUSSION}

\section{A. Dominant Height Growth}

Dominant height growth model was developed based on 32 PSPs of kayu bawang by applying the nested regression method. Results of analysis are expressed in equations (1) and (2). The coefficients of regression a0, ai, and

$$
\text { AMRES }=\frac{\sum\left|Y_{i}-\hat{Y}\right|}{n}
$$

$$
A P D=\frac{\sum \frac{\left|Y_{i}-\hat{Y}_{i}\right|}{Y i}}{n} \times 100 \%
$$


Table 4. Value of differential coefficient ai and intercept for the two models of kayu bawang dominant height growth in Bengkulu Province

\begin{tabular}{|c|c|c|c|c|c|c|}
\hline \multirow{2}{*}{$\begin{array}{l}\text { No } \\
\text { Plot }\end{array}$} & \multicolumn{3}{|c|}{ Model 1} & \multicolumn{3}{|c|}{ Model 2} \\
\hline & $a_{0}$ & $a_{i}$ & $a=a_{0+} a_{i}$ & $a_{0}$ & $a_{i}$ & $a=a_{0+} a_{i}$ \\
\hline 1. & 3.06 & - & 3.06 & 1.92 & - & 1.92 \\
\hline 2. & 3.06 & -0.05 & 3.01 & 1.92 & -0.75 & 1.17 \\
\hline 3. & 3.06 & 0.08 & 3.14 & 1.92 & 0.69 & 2.61 \\
\hline 4. & 3.06 & 0.14 & 3.20 & 1.92 & 1.59 & 3.51 \\
\hline 5. & 3.06 & 0.04 & 3.11 & 1.92 & 0.95 & 2.87 \\
\hline 6. & 3.06 & -0.12 & 2.94 & 1.92 & -0.92 & 1.0 \\
\hline 7. & 3.06 & -0.11 & 2.95 & 1.92 & -2.71 & -0.79 \\
\hline 8. & 3.06 & 0.12 & 3.18 & 1.92 & 1.55 & 3.48 \\
\hline 9. & 3.06 & -0.11 & 2.95 & 1.92 & -2.02 & -0.10 \\
\hline 10. & 3.06 & 0.09 & 3.15 & 1.92 & 0.55 & 2.47 \\
\hline 11. & 3.06 & 0.12 & 3.18 & 1.92 & 1.09 & 3.02 \\
\hline 12. & 3.06 & -0.58 & 2.48 & 1.92 & -6.14 & -4.22 \\
\hline 13. & 3.06 & 0.08 & 3.15 & 1.92 & 0.57 & 2.49 \\
\hline 14. & 3.06 & -0.31 & 2.76 & 1.92 & -3.26 & -1.34 \\
\hline 15. & 3.06 & 0.17 & 3.24 & 1.92 & 3.12 & 5.04 \\
\hline 16. & 3.06 & 0.33 & 3.39 & 1.92 & 6.24 & 8.17 \\
\hline 17. & 3.06 & 0.35 & 3.42 & 1.92 & 5.05 & 6.97 \\
\hline 18. & 3.06 & 0.20 & 3.27 & 1.92 & 2.64 & 4.57 \\
\hline 19. & 3.06 & 0.24 & 3.31 & 1.92 & 3.34 & 5.27 \\
\hline 20. & 3.06 & 0.36 & 3.42 & 1.92 & 5.04 & 6.96 \\
\hline 21. & 3.06 & 0.10 & 3.17 & 1.92 & 1.40 & 3.32 \\
\hline 22. & 3.06 & 0.13 & 3.19 & 1.92 & 2.68 & 4.60 \\
\hline 23. & 3.06 & 0.26 & 3.32 & 1.92 & 4.98 & 6.90 \\
\hline 24. & 3.06 & 0.23 & 3.29 & 1.92 & 4.21 & 6.13 \\
\hline 25. & 3.06 & 0.23 & 3.29 & 1.92 & 4.05 & 5.97 \\
\hline 26. & 3.06 & 0.22 & 3.29 & 1.92 & 3.32 & 5.24 \\
\hline 27. & 3.06 & 0.27 & 3.34 & 1.92 & 3.99 & 5.91 \\
\hline 28. & 3.06 & 0.19 & 3.26 & 1.92 & 3.44 & 5.36 \\
\hline 29. & 3.06 & 0.07 & 3.13 & 1.92 & 1.82 & 3.74 \\
\hline 30. & 3.06 & 0.07 & 3.13 & 1.92 & 1.76 & 3.69 \\
\hline 31. & 3.06 & 0.13 & 3.19 & 1.92 & 1.66 & 3.59 \\
\hline 32. & 3.06 & 0.12 & 3.19 & 1.92 & 1.78 & 3.71 \\
\hline
\end{tabular}

$\mathrm{b}$ for each equation are shown in Table 3. The coefficients ai for model 1 ranges from -0.58 to 0.36 and for model 2 from -6.14 to 6.24 (Table 4). The difference of coefficient ai shows that there is a difference in site quality among the plots. The lowest coefficient indicates the poorest site quality of the plot and adversely to the highest coefficient.
When the accuracy of the models was compared, both models performed reasonably well with high coefficient of determination $\left(\mathrm{R}^{2}>95 \%\right)$. However, model 1 ( $\mathrm{Ln} \mathrm{H0}=(3.06$ + ai) $-2.05 / \mathrm{A})$ compared to model $2(\mathrm{H} 0=$ $(1.92+$ ai $)+7.18 \ln \mathrm{A})$ is the better model for dominant height growth of kayu bawang because it has the lower deviation both AMRES 


\section{Dominant height $(\mathrm{m})$}

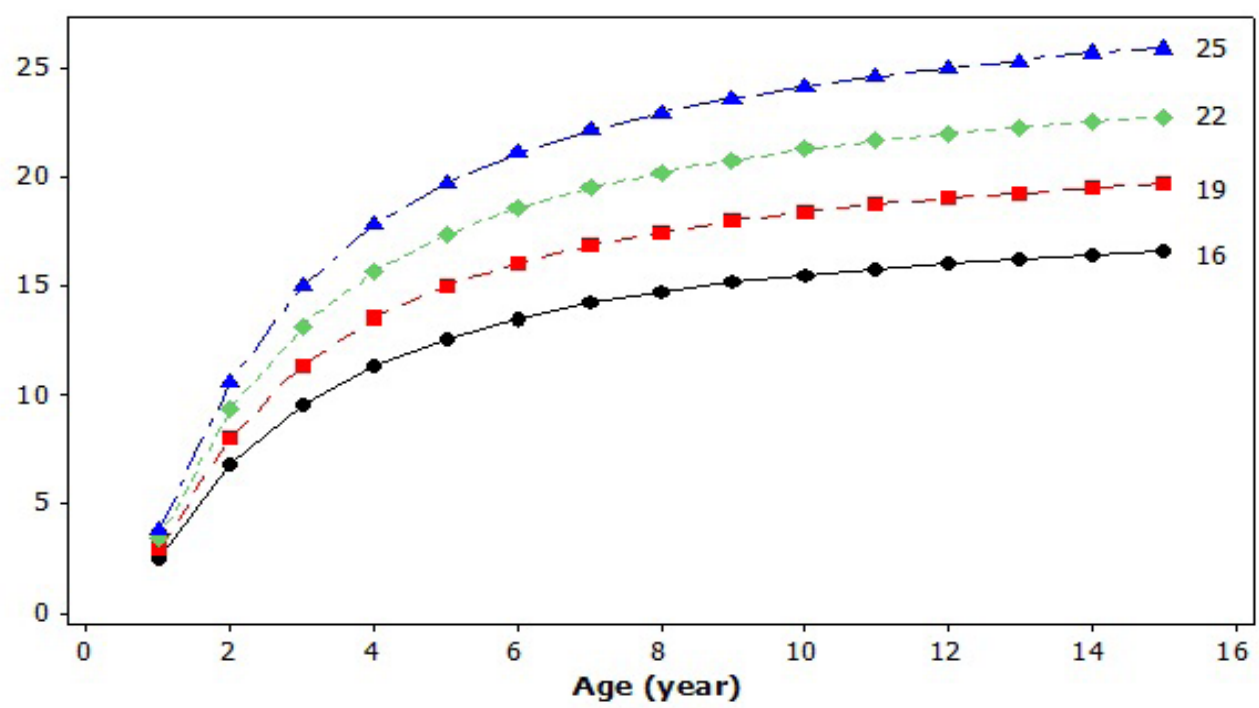

Figure 3. Dominant height curve of kayu bawang at Bengkulu Province for site indices 16, 19, 22, and 25

Table 5. The location of five site classes of kayu bawang stands in Bengkulu Province

\begin{tabular}{ccl}
\hline No. & $\begin{array}{c}\text { Site } \\
\text { classes }(\mathbf{m})\end{array}$ & \multicolumn{1}{c}{ Plot location (village) } \\
\hline 1. & $<16$ & Beringin III and Pelalo (Rejang Lebong) \\
\hline 2. & $16 \leq$ SI $<19$ & $\begin{array}{l}\text { Pasar Pedati, Pekik Nyaring, Dusun Baru (Centre Bengkulu); and Bandung } \\
\text { Marga (Rejang Lebong) }\end{array}$ \\
\hline 3. & $19 \leq$ SI $<22$ & $\begin{array}{l}\text { Talang IV, Talang Boseng (Centre Bengkulu); Sukaraja, Taba (Seluma); } \\
\text { Kp Delima, Pal VIII, Bandung Marga (Rejang Lebong); Lubuk Saung } \\
\text { (Kepahiang), Sawang Lebar, Padang Sepan, and Genting Perangkap } \\
\text { (North Bengkulu). }\end{array}$ \\
\hline 4. & $22 \leq$ SI $<25$ & $\begin{array}{l}\text { Lubuk Ladung (South Bengkulu); Dusun Curup, Genting Perangkap, and } \\
\text { Pagar Banyu (North Bengkulu) }\end{array}$ \\
\hline 5. & $>25$ & Batu Ampar, Pagar Dewa (South Bengkulu), and Bakal Dalam (Seluma). \\
\hline
\end{tabular}

and APD (Tabel 4). Model 1 was also used by Darwo (2012) to quantify site quality of Eucalyptus plantations in North Sumatra, but 10 based logarithms was used in the model. He used both equations of $\log \mathrm{OH}=1.48-0.69 / \mathrm{A}$ and $\log \mathrm{S}=\log \mathrm{OH}+0.69(1 / \mathrm{A}-1 / 8)$ to predict dominant height growth and site index of Eucalyptus in South Sumatra. Puspasari and Achmad (2000) also used the same model to predict site index for Acacia mangium in
Riau Province. The model used is anamorphic model i.e. $\log \mathrm{H}=1.59-0.94 / \mathrm{A}$ and $\log \mathrm{SI}$ $=\log \mathrm{H}-1.59(1 / \mathrm{A}-1 / 8)$. All the results of these studies showed that site classification by stand dominant height growth has become the most common and suitable practice for forest plantations in Indonesia, including smallholder plantations.

In selecting the most appropriate model, a compromise between biological and statistical 
Table 6. Correlation between site characteristics and site indices of kayu bawang in Bengkulu Province

\begin{tabular}{lcccccccc}
\hline Site characteristics & SI & Alt & RF & BD & Nt & P & K & Snd \\
\hline Alt & -0.541 & & & & & & & \\
RF & 0.014 & -0.076 & & & & & & \\
BD & 0.568 & -0.699 & 0.390 & & & & & \\
Nt & -0.313 & 0.836 & -0.244 & -0.790 & & & & \\
P & 0.396 & -0.099 & 0.377 & 0.247 & -0.130 & & & \\
K & 0.037 & 0.161 & 0.091 & 0.052 & 0.018 & 0.044 & & \\
Snd & -0.056 & 0.550 & -0.176 & -0.295 & 0.595 & -0.241 & -0.172 & \\
Cly & 0.190 & -0.747 & 0.083 & 0.366 & -0.713 & 0.183 & -0.063 & -0.854 \\
\hline
\end{tabular}

Remarks: $\mathrm{SI}=$ site index, Alt $=$ altitude $(\mathrm{m}$ asl.), $\mathrm{RF}=$ rainfall $(\mathrm{mm} /$ year), $\mathrm{BD}=$ bulk density $(\mathrm{g} / \mathrm{cm} 3), \mathrm{pH}=$ soil acidity, $\mathrm{Nt}=\mathrm{N}$ total $(\%), \mathrm{P}=$ phosphor $(\mathrm{ppm}), \mathrm{K}=\mathrm{Kalium}(\mathrm{me} / 100 \mathrm{~g}), \mathrm{Snd}=$ sand $(\%), \mathrm{Cly}=$ clay $(\%)$

considerations have been made, rather than a pure statistical inference (Krisnawati, 2007). Model 2, although it has a high coefficient of determination and small AMRES, produces an unrealistic prediction, the negative value of dominant height at younger ages for plots that have differential intercept ai $<-1.92$. For example, if ai $=-2.92$ at age $(A)=1$ year, based on model $2, \mathrm{H} 0=(1.92-2.92+7.18 \ln (1)$ $=-1$. Negative value of a dominant height is unrealistic; therefore, logically model 2 was not preferred.

\section{B. Site Index and Site Class}

Based on model 1 with the selected reference age of 12 years, the site index equation for kayu bawang was determined as: $\mathrm{Ln} \mathrm{Si}=\mathrm{Ln}$ H0 - 2.05 (1/12-1/A). Substituting differential intercept ai in the site index equation, then the site index of kayu bawang ranges between 10.09 and 28.50 meter. For site classification purposes, site indices were divided into 5 classes, with an equal range of 3 meters intervals. The following site classes were established: SI $<16$ m, $16 \mathrm{~m} \leq \mathrm{SI}<19 \mathrm{~m} ; 19 \mathrm{~m} \leq \mathrm{SI}<22 \mathrm{~m} ; 22$ $\mathrm{m} \leq \mathrm{SI}<25 \mathrm{~m}$; and $\mathrm{SI} \geq 25 \mathrm{~m}$ for site classes I, II, III, IV, and V respectively from the lowest to the highest productivity. Site classes can be expressed by a curve that shows the growth of the dominant height at one point of the site index. The five different site indices of 16, 19, 22, and 25 meters (Figure 3) are anamorphic curves, which consist of proportional site index curves. The curves are produced by five equations with different intercept (a) but with the same slope (b).

Based on this site classification, growth of kayu bawang in Bengkulu Province was divided into 5 site classes. The distribution of the location of each site class is shown in Table 5. Site class I (SI $<16 \mathrm{~m})$ was found only in Rejang Lebong District that constitutes of two PSPs in Beringin III and Pelalo villages. Site index II was found in Rejang Lebong and Centre Bengkulu District. The site that was categorized as the medium site class (Site index III) is located almost in all districts of Bengkulu Province, with the exception of South Bengkulu District. Site indices IV and V were found in South Bengkulu, North Bengkulu and Seluma District.

Site classification can be related to the physical environment variables such as altitude, rainfall, and soil characteristics (Table 6). Based on the coefficient of correlation as shown in Table 6, two environmental variables, altitude and soil bulk density, have significant effect on the site index of kayu bawang. Altitude has 
Table 7. The range of site characteristics for each site class of kayu bawang in Bengkulu Province

\begin{tabular}{lccccc}
\hline \multirow{2}{*}{ Site characteristic Site index (number of locations) } \\
\cline { 2 - 6 } & $\mathbf{I}(\mathbf{2})$ & II (4) & III (8) & IV (3) & V (3) \\
\cline { 2 - 6 } Alt & $873-974$ & $9-885$ & $8-923$ & $86-115$ & $12-277$ \\
& 924 & 238 & 405 & 105 & 111 \\
\hline RF & $2668-3528$ & $2782-3089$ & $2333-3876$ & $2500-3079$ & $2002-3956$ \\
& 2974 & 2993 & 2965 & 2886 & 3168 \\
\hline BD & $0.73-0.80$ & $0.60-1.15$ & $0.67-1.36$ & $0.93-1.49$ & $1.07-1.33$ \\
& 0.77 & 0.96 & 1.02 & 1.29 & 1.24 \\
\hline $\mathrm{Nt}$ & $0.39-0.41$ & $0.15-0.61$ & $0.17-0.54$ & $0.17-0.31$ & $0.17-0.38$ \\
& 0.40 & 0.29 & 0.32 & 0.24 & 0.25 \\
\hline $\mathrm{P}$ & $7.05-9.30$ & $2.25-14.1$ & $4.65-13.35$ & $5.55-6.75$ & $13.6-58.7$ \\
& 8.18 & 7.50 & 8.44 & 6.30 & 31.43 \\
\hline $\mathrm{K}$ & $0.19-0.38$ & $0.13-0.96$ & $0.19-1.28$ & $0.26-0.32$ & $0.19-0.58$ \\
& 0.29 & 0.46 & 0.45 & 0.28 & 0.34 \\
\hline Snd & $61.84-63.97$ & $39.67-71.68$ & $37.67-80.73$ & $58.78-65.58$ & $36.48-83.75$ \\
& 62.91 & 53.56 & 55.42 & 62.11 & 57.90 \\
\hline Cly & $7.66-8.17$ & $7.96-31.59$ & $7.76-36.59$ & $11.5-14.2$ & $7.61-32.6$ \\
& 7.92 & 24.26 & 20.21 & 13.14 & 20.88 \\
\hline
\end{tabular}

Remarks: $\mathrm{SI}=$ site index, Alt $=$ altitude $(\mathrm{m}$ asl. $), \mathrm{RF}=$ rainfall $\left(\mathrm{mm} \mathrm{year}^{-1}\right), \mathrm{BD}=$ bulk density $\left(\mathrm{g} \mathrm{cm}^{3-1}\right), \mathrm{pH}=$ soil acidity, $\mathrm{Nt}=\mathrm{N}$ total $(\%), \mathrm{P}=$ phosphor $(\mathrm{ppm}), \mathrm{K}=\mathrm{Kalium}(\mathrm{me} / 100 \mathrm{~g})$, Snd $=$ sand $(\%), \mathrm{Cly}=$ clay $(\%)$

negative effect on the site index, so the higher the altitude the poorer is the site index for kayu bawang. In line with this fact, both locations of site class I, the poorest site, was found on the upland areas at an altitude of $>850 \mathrm{~m}$ above sea level on andosol soil type. Adversely, the best site (site classes IV and V) were found on lowland areas with altitude $<300 \mathrm{~m}$ above sea level on ultisol soil type (Table 7).

The other physical characteristic that has significant correlation with site quality is bulk density. A positive correlation between site index and soil bulk density with $\mathrm{r}=0,568$ (Table 6 ) is caused by the fact that at low altitude, the location with the higher site index, the bulk density tended to increase until $1,49 \mathrm{gr} \mathrm{cm}^{3-1}$, so it seems that the increase in bulk density has positive effect on the site index. It was found that at the upland site soil bulk density was less than $0.9 \mathrm{gr} \mathrm{cm}^{3-1}$ and adversely at the lower sites it was higher than $0.9 \mathrm{gr} \mathrm{cm}^{3-1}$. Although the soil with low bulk density derived from amorphous or volcanic material (Hardjowigeno, 2003;
Sutanto, 2005; Rachim \& Arifin, 2011) was a fertile soil, the upland site of the soil caused some negative effect on site quality. On the upland site in Rejang Lebong it was found that the soil had low proportion of clay and adversely high proportion of sand. Usta, Yilmaz, and Altun (2013) confirms the negative correlation between altitude and clay content of the soil. The decrease of clay ratio on the upland site can be explained by the decrease in temperature. Although humidity (moisture) conditions were sufficient, the insufficient temperature level negatively affected the disintegration and thus, the amount of clay per unit volume of soil was found to be at low levels (Usta et al., 2013).

\section{CONCLUSION}

Site index equation based on the dominant height-age relationship as proposed by Schumacher was selected as the best model for classifying site quality of smallholder plantations of kayu bawang in Bengkulu Province.

The site quality of kayu bawang is classified 
into five classes with an equal range of $3 \mathrm{~m}$, i.e. SI $<16 \mathrm{~m} ; 16 \mathrm{~m} \leq \mathrm{SI}<19 \mathrm{~m} ; 19 \mathrm{~m} \leq \mathrm{SI}<22$ $\mathrm{m} ; 22 \mathrm{~m} \leq \mathrm{SI}<25 \mathrm{~m}$; and SI $\geq 25 \mathrm{~m}$ for site classes I, II, III, IV, and V, respectively from the poorest to the highest site productivity.

Site class I, the poorest site, was found on the upland site with an altitude of $>850 \mathrm{~m}$ above sea level on andosol soil type, adversely, the best site (site class V) was found on lowland areas with an altitude of $<300 \mathrm{~m}$ above sea level on ultisol soil type

\section{ACKNOWLEDGEMENT}

We thank Mr. Darwis for field assistance, and Mrs Anik Sriwahyuni SPKP, MSi for giving access to established PSP on her land. We also thank Mr. Kisno, SP, MSi and Efratenta, S.Hut., MSi, lecturers of Bengkulu University, for providing guidance in determining soil characteristic.

\section{REFERENCES}

Alder D. (1980). Forest volume estimation and yield prediction. Rome, Italy: Food and Agriculture Organization (FAO) of the United Nations.

Apriyanto, E. (2003). The Growth of Kayu Bawang (Protium javanicum Burm F.) in Monoculture Stand in North Bengkulu (in Bahasa Indonesia). Jurnal Ilmu-Ilmu Pertanian Indonesia, 5(2), 64-70. Retrieved from http//ejurnal. tripod.com/djipoid.html

Avery, T. E., \& Burkhart, H. E. (2002). Forest measurements. New York, USA: Mc. Graw-Hill Inc.

Beaulieu, J., Faulier, F., Pregent, G., \& Bousquet, J. (2011). Predicting site index from climatic, edaphic, and stand structural properties for seven plantation-grown conifer species in Quebec. Canadian Journal of Forest Research, 41, 682-693.

Bravo-Oviedo, A., Tome, M., Bravo, F., Montero, G., \& del Rio, M. (2008). Dominant height growth equations including site atrributes in the generalized algebraic differences. Canadian Journal of Forest Research, 38(9), 2348-2358. doi:10.1139/X08-077

Clutter, J. L., Fortson, J. C., Pienar, L. V., Brister, G. H., \& Bailey, R. L. (1983). Timber management: a quantitative approach. New York, USA: John Wiley \& Sons Inc.
Darwo, Suhendang, E., Jaya, I. . N. S., Purnomo, H., \& Pratiwi. (2012). Quantification Quality and Productivity of Growth Points stands for Sustainable Forest Plantation of Eucalyptus in Simalungun, North Sumatera (in Bahasa Indonesia). Jurnal Penelitian Hutan Tanaman, 9(2), 83-93.

Draper, N., \& Smith, H. (1992). Applied regression analysis. Jakarta: Gramedia Pustaka Utama.

Forest District of Bengkulu. (2003). Cultivation of Kayu Bawang (Protium javanicum Burm F.) (in Bahasa Indonesia). Bengkulu: Forest District of Bengkulu.

Harbagung. (1991). The Index Prediction Model of Growing Points of Eucalyptus deglupta Forest Plantation (in Bahasa Indonesia). Buletin Penelitian Hutan, (542), 19-36.

Hardjowigeno, S. (2003). Soil Classification and Pedogenesis (in Bahasa Indonesia). Jakarta: Akademika Pressindo.

Huang, S., Yang, Y., \& Wang, Y. (2003). A critical look at procedures for validating growth and yield models. In A. Amaro, D. Reed, \& P. Soares (Eds.), Modelling Forest Systems. London: CABI Publishing.

Husch, B. (1963). Forest mensuration and statistics. New York, USA: Ronald Press Company.

Khouri, E. A., Alvarez, P. A., Lopez, M. J. F., Prendes, J. A. O., \& Obregon, A. C. (2011). Influence of climate, edaphic factor and tree nutrition on site index of chesnut coppice stands in North-West Spain. Forestry, 84, 385-396.

Krisnawati, H. (2007). Modelling stand growth and yield for optimizing management of Acacia mangium Willd Plantation in Indonesia [doctorate thesis]. University of Melbourne, Australia.

Krisnawati, H., Wang Y., Ades P. K., \& Wild, I.W. (2009). Dominant height and site index models for Acacia mangium Willd. Plantations. Journal of Forestry Research, 6(2), 148-165.

Puspasari, D., \& Achmad, B. (2000). The Index Assessment Model of Growing Points for Acacia mangium Forest Plantation (in Bahasa Indonesia). Buletin Penelitian Kebutanan Pematang Siantar, 16(1), 41-52.

Rachim, D. A., \& Arifin, M. (2011). Fundamentals of Soil Taxonomy (in Bahasa Indonesia). Bandung: Pustaka Reka Cipta.

Scolforo, J. R. S., Maestri, R., Filho, A. C. F., de Mello, J. M., de Oliveira, A. D., \& de Assis, A. L. (2013). Dominant height model foe site classification of Eucalyptus grandis incorporating climatic varibles. International Journal of Forestry Research, 2013. doi:dx.doi. org $/ 10.1155 / 2013 / 139236$

Sharma, R. P., Brunner, A., \& Eid, T. (2012). Site 
index prediction from site and climate variables for Norway spruce and Scots pine in Norway. Scandinavian Journal of Forest Research, 27, 619-636.

Siahaan, H., Suhendang, E., Rusolono, T., \& Sumadi, A. (2011). The Growth of Kayu bawang (Disoxyllum mollissimum Bl.) Stands in different Planting Patterns and Density Stands (in Bahasa Indonesia). Jurnal Penelitian Hutan Tanaman, 8(4), 225-237.

Skovsgaard, J. P., \& Vanclay, J. K. (2008). Forest site productivity: A review of the evolution of dendrometric concepts for even aged stands. Forestry, 81(1), 12-31.

Sumadi, A., \& Siahaan, H. (2010). Volume Estimation Model of Kayu bawang (Disoxylum molliscimum Bl.) in Bengkulu Province (in Bahasa Indonesia). Jurnal Penelitian Hutan Tanaman, 7(5), 227-231.

Sutanto, R. (2005). Soil Science Basics (in Bahasa Indonesia). Yogyakarta: Penerbit Kanisius.
Tahar, S., March, P., Salah, G., Antonio, B. J., Youssef, A., \& Miriam, P. (2012). Modeling dominant height growth in planted Pinus pinea Stands in Northwest Tunisia. International Journal of Forestry Research, 2012. doi:10.1155/2012/902381

Usta, A., Yilmaz, M., \& Altun, L. (2013). Changing of the site index and soil characteristics in conjunction with the environmental factors in the pure oriental Spruce (Picea orientalis) Forest. Ekoloji, 22(89), 11-18.

Vanclay, J. K. (1994). Modelling forest growth and yield: application to mixed tropical forest. Wallingford, UK: CAB International. Retrieved from http://epubs.scu.edu.au/cgi/viewcontent. cgi? article $=1538 \&$ context $=$ esm_pubs

Vanclay, J. K., J., B., \& Cedamon, E. (2008). Site index equation for smallholder plantations of Gmelina arborea in Leyte Province, the Philippines. Small-Scale Forestry, 7(1), 87-93. 